\title{
Article/Artigo
}

\section{Evaluation of laboratory markers of progression of HIV disease to death}

\author{
Avaliação de marcadores laboratoriais de progressão da doença HIV para óbito
}

\begin{abstract}
Graça Maria de Castro Viana ${ }^{1}$, Maria do Desterro Soares Brandão Nascimento ${ }^{1,2}$, Aila de Menezes Ferreira ${ }^{3}$, Érica Milena Fernandes Rabelo ${ }^{4}$, João Arnaud Diniz Neto ${ }^{4}$, Carolina de Souza Galvão ${ }^{4}$, Alessandro Carvalho dos Santos ${ }^{4}$, Onildo Martins Santos Júnior ${ }^{4}$, Rodrigo Artur Souza de Oliveira ${ }^{4}$ and José Roberto Binda Júnior ${ }^{5}$
\end{abstract}

\begin{abstract}
Introduction: One of the important current problems in HIV/AIDS infection is the establishment of epidemiological and laboratorial prognostic parameters during patient followup. This study aimed at analyzing the evolution of laboratory tests: CD4 lymphocyte count, viral load, hemoglobin $(\mathrm{Hb})$, aspartate aminotransferase (AST), alanine aminotransferase (ALT), and the epidemiological variables sex and age as prognostic factors for survival in progression to death among AIDS patients. Methods: A retrospective study was conducted using analysis of medical records, and prospective 24-month follow-up of patients with HIV/ AIDS attended at the President Vargas Hospital Outpatient Clinic, a reference center in HIV/ AIDS attendance in the State of Maranhão, Brazil. The study analyzed patients aged 10 to 60 years old, who manifested AIDS and who were not using antiretroviral therapy or had used it for less than 5 years. The Chi-square test was used for statistical analysis. Results: The sample included 100 patients - 57 were current outpatients, and 43 had died. The variables viral load $(\mathrm{p}=0.726), \operatorname{ALT}(\mathrm{p}=0.314), \operatorname{sex}(\mathrm{p}=0.687)$, and age $(\mathrm{p}=0.742)$ were analyzed, and no evidence of association between them and worst prognosis was observed. Conclusions: A significant relation was verified between low Hb levels $(\mathrm{p}=0.000)$ and $\mathrm{CD} 4(\mathrm{p}=0.000)$ and shorter survival.
\end{abstract} Keywords: Risk factors. Prognosis. HIV/AIDS.

\section{RESUMO}

Introdução: Uma das importantes dificuldades atuais na infecção HIV/AIDS é estabelecer parâmetros epidemiológicos e laboratoriais prognósticos no seguimento dos pacientes. Esse trabalho objetivou analisar a evolução dos exames laboratoriais: contagem de linfócitos CD4, carga viral, dosagem de hemoglobina (Hb), de aspartato aminotransferase (AST), de alanino aminotransferase (ALT) e as variáveis epidemiológicas: sexo e idade, como fatores prognósticos de sobrevida na evolução para o óbito em pacientes com AIDS. Métodos: Foi realizado um estudo retrospectivo a partir da análise de prontuários e um prospectivo por seguimento de pacientes portadores de HIV/AIDS, no Serviço Ambulatorial da referência assistencial em HIV/AIDS, no Estado do Maranhão, durante 24 meses. Os pacientes analisados tinham faixa etária compreendida entre 10 e 60 anos, apresentavam quadro clínico manifesto e não faziam uso de antirretroviral ou ainda o faziam há menos de 5 anos. Para análise estatística, foi adotado o teste qui-quadrado. Resultados: A amostra compreendeu 100 pacientes, dos quais 57 se encontravam em tratamento ambulatorial e 43 já tinham ido a óbito. Variáveis como carga viral $(\mathrm{p}=0,726), \operatorname{ALT}(\mathrm{p}=0,314)$, sexo $(\mathrm{p}=0,687)$ e faixa etária $(\mathrm{p}=0,742)$ foram analisadas e nenhuma evidência de associação entre elas com o pior prognóstico foi verificada. Conclusões: Constatou-se uma significante relação entre baixos níveis de $\mathrm{Hb}(\mathrm{p}=0,000)$ e de CD4 ( $\mathrm{p}=0,000)$ com menor sobrevida.

Palavras-chaves: Fatores de risco. Prognóstico. HIV/AIDS.

\footnotetext{
1. Departamento de Patologia, Universidade Federal do Maranhão, São Luis, MA. 2. Centro de Estudos Superiores de Caxias, Universidade Estadual do Maranhão, Caxias, MA. 3. Residência Médica em Cirurgia, Hospital Universitário, Universidade Federal do Maranhão, São Luis, MA. 4. Curso de Medicina, Universidade Federal do Maranhão, São Luis, MA. 5. Curso de Medicina, Centro Universitário do Maranhão, São Luis, MA.

Address to: Dra. Graça Maria de Castro Viana. Rua Nova, Quadra H, Casa 2. Sítio Leal, 65041-140 São Luis, MA, Brasil.

Phone: 5598 3223-1314

e-mail: gracaviana@globo.com

Received in $27 / 12 / 2010$

Accepted in 01/06/2011
}

\section{INTRODUCTION}

A total of 39.5 million people live with HIV/AIDS worldwide. The countries most affected are located in Eastern Europe, East and Central Asia, and Africa. Of the total number of people with HIV, $63 \%$ live in Africa, and this continent is an important focus of the epidemic. Moreover, about three-quarters of adult and child deaths caused by AIDS occur in this region.

In Latin America, 1.7 million people are living with HIV/AIDS ${ }^{1}$. The greatest incidence of HIV/ AIDS cases in Brazil is registered in the Southeast region, especially in São Paulo, where the greater portion of the country's population is concentrated ${ }^{2}$.

The first reported case of AIDS in an individual residing in the State of Maranhão occurred in 1985. Currently, the state is responsible for approximately $10 \%$ of cases in the Northeast region, occupying the fourth position in absolute numbers of cases among all the states in the region ${ }^{2}$.

In a number of countries, the mean survival time of patients infected by HIV/AIDS has changed. In Brazil, studies reveal that in the 1980s and early 1990s, the mean survival was 5 months ${ }^{3}$. In patients diagnosed in 1995 and 1996, the mean survival increased to 18 and 58 months, respectively ${ }^{4}$. More recently, in 2002, a mean survival time of 7 years was reported ${ }^{5}$.

Several factors are implicated in the prolonged survival of patients with AIDS, including improved services, early diagnosis, the introduction of antiretroviral (ARV) therapy, laboratorial follow-up, and the values of markers of disease progression such as viral load and CD4 $\mathrm{T}$ lymphocytes ${ }^{5}$.

Numerous clinical trials have shown a strong association between ARV therapy and clinical status and have reported improved prognosis, which resulted in the inclusion of these drugs in the treatment of AIDS patients ${ }^{4,6}$.

CD4 $\mathrm{T}$ cell counts of peripheral blood have prognostic implications for the evolution of HIV, as they are the most useful form of determining cellular immunocompetence during patient follow-up ${ }^{7}$. 
Some studies indicate that at each level of CD4 T lymphocytes, patients with higher viral load have a correspondingly higher risk of progression to AIDS or death during the subsequent years ${ }^{8}$.

According to the article Testes de função hepática e sobrevida em indivíduos com HIV/AIDS (Liver function tests and survival in individuals with HIV/AIDS) published in the XIV International AIDS Conference that took place from July 7-12, 2002 in Barcelona, minimal to moderate elevations of transaminases, alanine aminotransferase (ALT), and aspartate aminotransferase (AST) are associated with increased risk of mortality in individuals with AIDS. Moreover, it was reported that levels of hemoglobin $(\mathrm{Hb})$ below $1 \mathrm{~g} / \mathrm{dL}$ correlated with a six-fold increase in mortality ${ }^{9}$.

The seriousness of this epidemic disease and its ethical, social, and economic implications justify the study and the analysis of prognostic factors of mortality in HIV/AIDS, which should provide tools for the management and control of the disease in these patients throughout their evolution.

New markers for poor prognosis of AIDS could detect cell damage even before currently established laboratory tests, warning of the onset of complications, are installed. It is necessary, therefore, to investigate potential new prognostic markers in HIV disease, including the levels of $\mathrm{Hb}$, AST, and ALT; sex; and age, while also corroborating laboratory markers established in the literature such as load viral quantification and CD4 T lymphocyte counts. These constitute the principal objectives of this work.

\section{METHODS}

\section{Casuistic/sample}

The study involved retrospective analysis of the past 2 years of medical records of patients with HIV/AIDS who attended at the President Vargas Hospital (HPV), Outpatients Clinic, a reference hospital unit for HIV/AIDS attendance in the State of Maranhão. It also involved a prospective study involving 24 months follow-up that included patients who met the criteria of the study protocol: individuals presenting manifestation of AIDS, aged 10 to 60 years old, and who had not used ARVs or who had used them for less than 5 years (presumed reduction in medication toxicity).

\section{Study outline}

The following epidemiological - sex and age - and laboratorial data - Hb, CD4, viral load, and AST and ALT levels - were analyzed, and the normal parameters used were: $\mathrm{Hb}(12-17 \mathrm{~g} / \mathrm{dL})$, AST (16-40IU/L), ALT (8-54IU/L), CD 4 ( $\geq 200$ cells $\left./ \mathrm{mm}^{3}\right)$, and viral load $(<100,000 \mathrm{cps} / \mathrm{mL})$.

\section{Statistical analysis}

The results were evaluated and transferred to a specific database using STATA software. The variables studied were analyzed using the Chi-square test and a significance level of $\mathrm{p}<0.05$ was adopted.

\section{Ethical considerations}

The investigative process was conducted in accordance with the ethical guidelines established by Resolution 196/96 of the Brazilian National Health Council and the Helsinki Declaration of 1964, revised in 2000. This research was approved by the Research Ethics Committee of the President Dutra University Hospital of the Federal University of Maranhão.

\section{RESULTS}

Of the 400 medical records reviewed, 300 were discarded for various reasons: patient refusal to participate in the research, treatment abandonment, voluntary transfer to a treatment unit in another state, or the patient did not meet the inclusion criteria of the study protocol.

Thus, the sample comprised 100 patients; 57 patients were being attended - 19 women and 38 men, while 43 had died - 16 women and 27 men (Table 1).

Regarding patient sex, a mortality rate of $46 \%$ was determined for women and $42 \%$ for men, revealing no significant differences between the sexes $(\mathrm{p}=0.687)$ or association with poor prognosis of HIV/AIDS (Table1).

The age group with the highest percentage of death was 31 to 40 years old (48\%), followed by individuals aged 20 to 30 years old (46\%); however, no significant association was determined between age and shorter survival $(\mathrm{p}=0.742)$.

Among the 43 deaths, $81.4 \%$ (35) presented a mean $\mathrm{Hb}<12 \mathrm{~g} / \mathrm{dL}$, while among the 57 patients followed-up, only $33.3 \%$ (19) presented mean levels less than this parameter. Thus, the difference in the incidence of deaths among those with concentrations of $\mathrm{Hb} \geq 12 \mathrm{~g} / \mathrm{dL}$ (18.6\%) compared with those with $\mathrm{Hb}$ concentrations $<12 \mathrm{~g} / \mathrm{dL}$ (81.4\%) was significant ( $\mathrm{p}=0.000)$ (Table 1 ).

Regarding CD 4 counts, of the 43 patients who died, 33 (76.7\%) presented a mean CD 4 count $<200$ cells $/ \mathrm{mm}^{3}$, while among patients in treatment, only $19(33.3 \%)$ presented CD4 counts less than this value, and the majority (66.7\%) showed higher values for this parameter (Table 1). The difference in the incidence of deaths among individuals with CD4 concentrations $\geq 200$ cells $/ \mathrm{mm}^{3}$ (23.3\%) compared with those with CD4 concentrations $<200$ cells $/ \mathrm{mm}^{3}$ (76.7\%) was significant $(\mathrm{p}=0.000)$ (Table $\mathbf{1})$.

\begin{tabular}{|c|c|c|c|c|}
\hline \multirow[b]{2}{*}{ Sociodemographic characteristics } & \multicolumn{2}{|c|}{ Patients } & \multicolumn{2}{|c|}{ Deaths } \\
\hline & $\mathbf{n}$ & $\%$ & $\mathbf{n}$ & $\%$ \\
\hline \multicolumn{5}{|l|}{ Gender } \\
\hline male & 38 & 66.7 & 27 & 62.7 \\
\hline female & 19 & 33.3 & 16 & 37.3 \\
\hline \multicolumn{5}{|l|}{ Hemoglobin } \\
\hline$<12 \mathrm{~g} / \mathrm{dL}$ & 19 & 33.3 & 35 & 81.4 \\
\hline$>12 \mathrm{~g} / \mathrm{dL}$ & 38 & 66.7 & 8 & 18.6 \\
\hline \multicolumn{5}{|l|}{ CD4 } \\
\hline$<200$ cells $/ \mathrm{mm}^{3}$ & 19 & 33.3 & 33 & 76.7 \\
\hline$>200$ cells $/ \mathrm{mm}^{3}$ & 38 & 66.7 & 10 & 23.3 \\
\hline
\end{tabular}

CD4: Cluster of differentiation 4.

The percentage of patients presenting a viral load $>100,000$ copies/mL who died was $40 \%$, whereas $60 \%$ of patients who presented a viral load $>100,000$ copies $/ \mathrm{mL}$ had no fatal outcome. The analysis verified that high viral load was not statistically significant $(\mathrm{p}=0.726)$ and had no association with progression to death in infection with HIV/AIDS.

The percentage of patients with AST concentrations $>40 \mathrm{UI} / \mathrm{L}$ who died was $55 \%$, whereas only $32 \%$ of patients with concentrations remaining below this value had the same outcome, revealing a significant difference for this parameter $(\mathrm{p}=0.019)$. 
Regarding ALT concentrations, $45 \%$ of patients with concentrations $\leq 54 \mathrm{UI} / \mathrm{L}$ and $33 \%$ of patients with concentrations $>54 \mathrm{UI} / \mathrm{L}$ died. No association was determined between ALT and lower survival in patients $(\mathrm{p}=0.314)$.

\section{DISCUSSION}

This work corroborates previous findings of a higher prevalence of men infected with HIV/AIDS; 65\% of the present casuistic/ sample were male. In a study involving 200 patients in a hospital in Ribeirão Preto, in the State of São Paulo, Brazil, a rate of 59\% male patients was determined ${ }^{10}$, while Cavassani et al. ${ }^{11}$ found $69.1 \%$; however, in the current phase of the disease, an increased incidence of infection among women is occurring ${ }^{12}$.

Although the sex factor was not significant in this work, other studies have reported important differences. In a cohort of 139 women and 7,045 men, studied between July 1981 and December 1990 in San Francisco, CA, USA, Lemp et al. ${ }^{13}$ reported a lower overall mean survival for women. Moore et al. ${ }^{14}$ determined a statistically significant difference in prognosis between the sexes, with a higher risk of death for women. In another study involving 1,403 patients in a clinic in Londrina, PR, Brazil, Mocroft et al. ${ }^{15}$ reported that women were less likely to start treatment with antiretroviral drugs, which could impact the mortality rate for this group.

This trend is explained in other studies by the differences in cultural understanding between social groups. The socialization of Brazilians as men and women, that is, the sociocultural construction of gender relations, is the main obstacle to the perception of vulnerability to infection by HIV and has been largely neglected in the organization of patient care. Social norms deny women the knowledge regarding sexuality and reproductive health, which limits their chances of having control over their bodies and deciding how and with whom they wish to have sex. In Brazil, women, especially those in stable relationships, cannot demand the use of condoms or refuse sexual relations, as this can generate suspicions of infidelity ${ }^{16}$.

In a study involving 1,837 patients in the City of São Paulo, Gabriel et al. ${ }^{17}$ verified the highest percentage (46.8\%) of infected individuals in the age range of 30 to 39 years old, while Cavassan et al. ${ }^{11}$ reported the highest percentage $(47.1 \%)$ in the age range of 31 to 40 years old. Gir et al..$^{10}$ determined a median age of 38.2 years old, while it was 36 years old in the study of Lewden ${ }^{18}$. All these findings are in agreement with the prevalence determined in this work.

In contrast to this study, Moore et al. ${ }^{14}$ verified a relation between survival and age, reporting worse prognosis in patients over 45 years old, which was also found in the cohorts of São Paulo, Brazil ${ }^{19}$. Survival analysis of all individuals younger than 20 years old could not be performed, as the study sample comprised only one patient in this age group.

While studying a prospective cohort of 1,155 patients in France, Lewden et al. ${ }^{18}$ verified that low $\mathrm{Hb}$ levels were independently associated with mortality in patients infected with HIV/AIDS; $\mathrm{Hb}$ level is not a marker of disease progression and/or death in HIVinfected children, according to the study of Carvalho ${ }^{20}$. This finding is not consistent with that reported by Justice et al. ${ }^{9}$ and with this work, where an important level of significance was verified.

Low levels of CD4 are associated with poor prognosis in AIDS, a fact observed in the present casuistic/sample and by both Justice et al. ${ }^{9}$ and Lewden et al. ${ }^{18}$. CD4 cell count is a good marker of the risk of disease progression ${ }^{21}$.
Regarding viral load quantification, this work is in agreement with what was reported by Justice et al. ${ }^{9}$, that is, it is not possible to affirm a correlation between viral load and mortality in these patients.

Quantification of high levels of AST and the association of this variable with greater risk of mortality in patients with HIV/AIDS corroborate the findings of Justice et al. ${ }^{9}$ and Lewden et al. ${ }^{18}$. Martin et al. ${ }^{22}$ explained that this increase in transaminase was probably due to liver toxicity related to the use of ARV medications, affirming that certain ARVs, particularly nevirapine and ritonavir, are more frequently associated and that patients coinfected with hepatitis $\mathrm{B}$ and $\mathrm{C}$ virus are more likely to suffer from this toxicity.

In contrast to the AST results, observation of ALT concentrations revealed no association between high ALT levels and poor prognosis, which could reflect greater the sensitivity of AST in relation to ALT; however, this finding is in disagreement with some studies in which concomitant increases in transaminases were reported as factors associated with shorter survival ${ }^{4,9}$.

In conclusion and also for the Ministry of Health of Brazil, among the well-established laboratory markers, only the importance of CD4 counts was confirmed, while the same was not true for viral load quantification. Regarding new laboratory markers, hemoglobin and aspartate aminotransferase may be considered high-risk factors for death, while the same risk was not observed for alanine aminotransferase. Epidemiological data, age and sex, do not contribute to a greater or lesser life span in these patients. Thus, CD4 $\mathrm{T}$ lymphocytes, hemoglobin, and aspartate aminotransferase were significant predictors of survival in patients with AIDS.

\section{CONFLICT OF INTEREST}

The authors declare that there is no conflict of interest.

FINANCIAL SUPPORT

Institutional Program for Scientific Initiation Grants (Programa Institucional de Bolsas de Iniciação Científica, PIBIC).

\section{REFERENCES}

1. The Joint United Nations Programme on HIV/AIDS. AIDS epidemic Update 2006 [Internet]. Unaids; 2006 [cited 2007 March 10]. Available from: http:// www.unaids.org.br/.

2. Ministério da Saúde. Boletim Epidemiológico AIDS. v. 3 n. 1. Brasília: Ministério da Saúde; 2006.

3. Chequer P, Hearst N, Hudes ES, Castilho E, Rutherford G, Loures L, et al. Determinants of survival in adult Brazilian AIDS patients, 1982-1989. AIDS 1992; 6:483-487.

4. Marins JR, Jamal LF, Chen SY, Barros MB, Hudes ES, Barbosa AA. Dramatic improvement in survival among adult Brazilian AIDS patients. AIDS 2003; 17:1675-1682.

5. Gadelha AJ, Accacio N, Costa RL, Galhardo MC, Cotrim MR, Souza RV Morbidity and survival in advanced AIDS in Rio de Janeiro. Rev Inst Med Trop 2002; 44:179-186.

6. Menesia EO, Passos ADC, Monteiro ME, Dal-Fabbro AL, Laprega MR. Sobrevalência de pacientes com AIDS em uma cidade do sudeste brasileiro. Rev Pan Saude Publica 2001; 10:29-36.

7. Desimone JA, Pomerante JA. New methods for detection of HIV. Clin Lab Med 2002; 22:573-592.

8. Rachid M, Schecheter M. Manual de HIV/AIDS. $8^{\text {th }}$ ed. Rio de Janeiro: Revinter; 2005. 
9. Justice AC, Chang $\mathrm{CH}$, Fusco J, West $\mathrm{N}$. Testes de função hepática e sobrevida em indivíduos com HIV/AIDS. Paper presented at: XIV International AIDS Conference; 2003. July 7-12; Barcelona, Spain.

10. Gir E, Vaichulenis $\mathrm{CG}$, Oliveira $\mathrm{MD}$. Adesão à terapêutica antiretroviral por indivíduos com HIV/AIDS assistidos em uma instituição do interior paulista. Rev Lat Am Enfermagem 2005; 13:634-641.

11. Cavassani VGS, Andrade Sobrinho J, Homem MGN, Rapoport A. Candidíase oral como marcador de prognóstico em pacientes portadores do HIV. Rev Bras Otorrinolaringol 2002; 68:630-634.

12. Lopes CR. Vinte cinco anos de AIDS: novos números da epidemia. Radis Comunicação em Saúde 2007; 53:24.

13. Lemp GF, Hirozawa AM, Cohen JB, Derish PA, McKinney KC, Hernandez SR. Survival for women and men with AIDS. J Infect Dis 1992; 166:74-79.

14. Moore RD, Hidalgo J, Sugland BW, Chaisson RE. Zidovudine and natural history of the acquired immunodeficiency Syndrome. New Engl J Med $1991 ; 324: 1412-1416$.

15. Mocroft A, Gill MJ, Davidson W, Phillips AN. Are there gender differences in starting protease inhibitors, HAART, and disease progression despite equal access to care? J Acquir Immune Defic Syndr 2000; 24:475-482.

16. Buchalla CM, Paiva V. Da compreensão da vulnerabilidade social ao enfoque multidisciplinar. Rev Saude Publica 2002; 36:108-116.

17. Gabriel R, Barbosa DA, Vianna LA. Epidemiological profile of outpatients with HIV/AIDS at a school hospital - São Paulo city. Rev Lat Am Enfermagem 2005; 13:509-513.

18. Lewden $\mathrm{C}$, Héripret L, Bonnet F. Fatores associados à mortalidade em adultos infectados pelo vírus da imunodeficiência humana tipo-1 em início de terapêutica com inibidores da protease: papel do nível de escolaridade e do aumento precoce do valor de transaminases. J Infect Dis 2002; 186:710-714.

19. Tancredi MV. Sobrevida de pacientes com HIV e AIDS nas eras pré e pós terapia antirretroviral de alta potência. [Tese Doutorado]. [São Paulo]: Universidade de São Paulo; 2010. 140 p.

20. Carvalho IR, Pinto JA, Cardoso CAA, Candiani TMS, Kakehasi FM. Evaluation of hematological, virologic and anthropometric parameters as progression markers in HIV-1 infected children. J Pediatr 2009; 85:149-156.

21. Gupta V, Gupta S. Laboratory markers associated with progression of HIV infection. Indian J Med Microbiol 2004; 22:7-15.

22. Martín-Carbonero L, Núñez M, Ríos P, Pérez-Olmeda M, González-Lahoz J, Soriano V. Liver injury after beginning antiretroviral therapy in HIV/ hepatitis $\mathrm{C}$ virus co-infected patients is not related to immune reconstitution. AIDS 2002; 16:1423-1425. 